\title{
STUDI KOMPARASI PEMBELAJARAN TEAM ASSISTED INDIVIDUALIZATION (TAI) BERKOMBINASI DRILL AND PRACTICE DAN PROBLEM SOLVING BERBANTUAN PEER TUTORING DITINJAU DARI KEMAMPUAN METAKOGNISI TERHADAP PRESTASI BELAJAR SISWA (Materi Stoikiometri Kelas X MIPA SMA Negeri 1 Boyolali Semester Genap Tahun Ajaran 2016/2017)
}

\author{
Citra Choirunnisa, Ashadi ${ }^{\star}$, dan Suryadi Budi Utomo \\ Program Studi Pendidikan Kimia, FKIP, Universitas Sebelas Maret, Surakarta, Indonesia \\ *Keperluan korespondensi, telp/fax: +62816671690,email: ashadi_uns@yahoo.com
}

\begin{abstract}
ABSTRAK
Penelitian ini bertujuan untuk mengetahui: (1) pengaruh model pembelajaran TAI berkombinasi Drill and Practice dan Problem Solving berbantuan Peer Tutoring terhadap prestasi belajar pada materi Stoikiometri,(2) pengaruh kemampuan metakognisi terhadap prestasi belajar pada materi stoikiometri,(3) interaksi antara model pembelajaran TAI berkombinasi Drill and Practice dan Problem Solving berbantuan Peer Tutoring dengan kemampuan metakognisi terhadap prestasi belajar pada materi stoikiometri. Penelitian ini menggunakan metode eksperimen dengan desain faktorial $2 \times 2$. Subjek penelitian ini yaitu siswa kelas X MIPA 4 dan X MIPA 6 SMA N 1 Boyolali tahun ajaran 2016/2017 yang diambil dengan teknik cluster random sampling. Analisis data penelitian ini menggunakan uji Analisis Variansi (ANAVA) Dua Jalan dan uji Kruskal Wallis. Hasil penelitian menunjukkan: (1) terdapat pengaruh model pembelajaran TAl berkombinasi Drill and Practice dan Problem Solving berbantuan Peer Tutoring terhadap prestasi belajar aspek pengetahuan, tetapi tidak terdapat pengaruh terhadap aspek sikap dan keterampilan pada materi stoikiometri. (2) Tidak terdapat pengaruh kemampuan metakognisi terhadap prestasi belajar aspek pengetahuan, aspek sikap dan keterampilan pada materi stoikiometri. (3) Tidak terdapat interaksi antara model pembelajaran TAl berkombinasi Drill and Practice dan Problem Solving berbantuan Peer Tutoring dengan kemampuan metakognisi terhadap prestasi belajar aspek pengetahuan, sikap, dan keterampilan pada materi stoikiometri.
\end{abstract}

Kata Kunci: TAl berkombinasi Drill and Practice, Problem Solving berbantuan Peer Tutoring, Metakognisi, Prestasi Belajar, Stoikiometri

\section{PENDAHULUAN}

Perkembangan pendidikan di Indonesia identik dengan pembaharuan dalam komponen kurikulum. Perubahan kurikulum di Indonesia telah dimulai sejak tahun 1968 yaitu kurikulum Sekolah Dasar, hingga saat ini digunakan kurikulum 2013. Dampak yang diharapkan dari penyempurnaan kurikulum adalah pembelajaran yang terjadi tidak hanya sekedar melakukan pendekatan pembelajaran maupun model pembelajaran yang telah ada. Pembelajaran harus bertindak secara menyeluruh dan disesuiakan dengan sasaran yang dimaksud, sehingga dapat meningkatkan hasil pembelajaran (Hamalik, 2004) Sesuai dengan tujuan pendidikan nasional yang tercantum dalam UU Nomor 20 tahun 2003 bahwa pendidikan diharapkan dapat membentuk watak serta peradaban bangsa yang lebih bermartabat.

Keistimewaan dari kurikulum 2013 adalah pembelajaran akan berbasis student centered. Dimana peran siswa dalam aktivitas pembelajaran akan lebih dominan, dan guru hanya berperan sebagai fasilitator serta mediator. Siswa diharapakan mengembangkan keteram- 
pilan yang meliputi kemampuan dalam mengobservasi, bertanya, menalar, dan mengomunikasikan [1]. Berdasarkan data analisis hasil TIMSS (Trends in International Mathematics and Science Study), 95\% siswa Indonesia hanya mampu sampai pada level menengah, yaitu level mengaplikasikan (applying) dari total 6 level kemampuan [2].

Hal tersebut mengindikasikan bahwa pelajaran yang diberikan di dunia pendidikan Indonesia belum memenuhi tuntutan zaman. Pembelajaran diarahkan untuk mendorong peserta didik mencari tahu dari berbagai sumber dan bukan diberi tahu, sehingga nantinya siswa tidak hanya sekedar menyelesaikan masalah (menjawab) melainkan dapat merumuskan masalah. Pada akhirnya, kurikulum 2013 diharapkan dapat menghasilkan siswa yang produktif, kreatif, afektif dan inovatif melalui cara berfikir yang global.

Pembelajaran kimia di tingkat Menengah Atas banyak dianggap sulit oleh siswa. Hal ini karena karakteristik materi pembelajaran yang cenderung berisi konsep abstrak, tidak memiliki wujud, dan mengunakan skala atomik. Sebgaimana representasi konsep kimia berdasarkan segitiga Johnstone mengkategorikan dalam 3 level konsep, yaitu makroskopis, submikroskopis, dan simbolik [3].

Stoikiometri menjadi penting untuk dikaji karena karakteristik materi yang berisi dasar-dasar dari kimia kuantitatif. Pemahaman konsep dasar pada stoikiometri dapat mendukung pemahaman konsep lain pada pokok bahasan selanjutnya. Menurut Hanson [4], siswa memiliki pemahaman yang salah dan lemah dalam mengaitkan antara level mikroskopis dan level makroskopis dalam kimia yang menuntun siswa mengalami masalah pemahaman konsep dalam mempelajari stoikiometri. Hal ini dikarenakan karakteristik lain yang dimiliki pokok bahasan stoikiometri adalah berisi rumus-rumus dan persamaan berkaitan dengan perhitungan kimia. Dalam pokok bahasan stoikiometri, khususnya sub materi konsep mol dan stoikiometri reaksi siswa diharapkan memiliki kemampuan pemecahan masalah yang baik.

Data yang dikeluarkan Badan Standar nasional Pendidikan (BSNP) menunjukkan, daya serap siswa SMA di
Kabupaten Boyolali terhadap materi stoikiometri yang diujikan tergolong rendah. Pencapain Ujian Nasional pada indikator menginterpretasi persamaan reaksi yang diperoleh tahun 2016 di Kabupaten Boyolali adalah 40,12 dan tingkat provinsi Jawa Tengah adalah 42,27 . Sedangkan pada indikator menyelesaikan perhitungan kimia capaian Kabupaten Boyolali adalah 52,19 dan provinsi Jawa Tengah adalah 59,31. Hal ini mengindikasikan bahwa materi stoikiometri merupakan materi yang masih sulit dipahami oleh siswa.

Berdasarkan permasalahan di atas, diperlukan suatu cara yang tepat dalam menyampaikan materi stoikiometri yaitu dengan model pembelajaran yang sesuai dengan karakteristik pokok materi tersebut.Terdapat beberapa model pembelajaran yang sesuai antara lain model pembelajaran Team Assisted Individualization (TAI) yang dikombinasi dengan drill and practice dan model pembelajaran Problem Solving berbantuan peer tutoring.

Model pembelajaran TAI adalah suatu model pembelajaran dimana dalam satu kelompok terdapat seorang siswa yang dianggap lebih mampu berperan sebagai asisten untuk membantu anggota kelompoknya yang kurang mampu. Dengan kata lain, TAl dirancang untuk mengatasi kesulitan belajar siswa secara individu dengan bantuan seorang asisten [5]. Untuk meningkatkan hasil dari kerja kelompok model TAI dapat dikombinasikan dengan drill and practice.

Drill and practice merupakan suatu teknik yang berisi kegiatan berulang yang dilakukan siswa terhadap suatu bahan pembelajaran yang telah diberikan dengan tujuan menguasai keterampilan tertentu [6]. Model drill and practice cocok diterapkan pada pembelajaran yang mengandung hitungan, bahasa asing, dan aktivitas fisik.

Dari hasil penelitian yang dilakukan oleh Awofala [7] menunjukkan bahwa penggunaan model pembelajaran TAI pada mata pelajaran matematika dapat bekerja efektif dalam meningkatkan hasil belajar siswa daripada model pembelajaran konvensional. Selain itu, Sari [8] menyimpulkan bahwa penggunaan 
model pembelajaran TAI memberikan hasil prestasi belajar yang lebih baik dibanding dengan model CPS pada materi kelarutan dan hasil kali kelarutan.

Model pembelajaran problem solving merupakan salah satu model pembelajaran yang cukup kompleks karena dalam pelaksanaannya siswa dituntut untuk dapat merumuskan masalah sampai evaluasi tindakan. Terdapat 5 tahap dalam model problem solving yaitu tahap indentifikasi masalah, mendefinisikan tujuan, mencari kemungkinan-kemungkinan strategi, mengantisipasi hasil akhir dan tindakan, evaluasi dan proses belajar [9]. Salah satu alternatif perpaduan model pembelajaran adalah dengan mengombinasikan dengan peer tutoring. Dengan bantuan peer tutoring, dalam proses pemecahan masalah terdapat seorang siswa dalam kelompok yang berperan sebagai tutor untuk membantu siswa lain yang pemahamannya masih rendah. Selain pembelajaran berjalan dengan aktif, diharapkan pemahaman rata-rata juga meningkat. Penelitian yang dilakukan oleh Ishartono menunjukkan bahwa problem solving berbantuan peer tutoring yang dilengkapi hierarki konsep dapat meningkatkan kualitas proses dan hasil belajar pada materi stoikiometri [10].

Faktor internal dalam diri siswa yang dapat mempengaruhi prestasi belajar materi stoikiometri salah satunya adalah kemampuan metakognisi. Flavell mendefinisikan metakognisi sebagai pengetahuan mengenai proses kognitif atau segala hal yang berhubungan dengan ranah kognitif yang dimiliki [11]. Lebih jaul Flavell (1985) mengungkapkan kemampuan metakognisi diyakini berperan penting dalam berbagai jenis aktivitas kognitif, termasuk mengomunikasikan informasi secara oral, pemahaman bacaan, kemahiran berbahasa, memori, pemecahan soal, kognisi sosial, dan berbagai jenis pengajarsn diri dan kontrol diri [12].

Setiap disiplin ilmu memiliki cara dan karakteristik masing-masing dalam hal penalaran Sebagai contoh dalam pembelajaran kimia, perlu adanya membuat hubungan antara pengamatan makroskopis dengan penjelasan pada level molekular. Hal ini untuk mem- bangun pemahaman yang baik dalam mempelajari kimia. Dengan demikian, mengajarkan keterampilan metakognitif pada mata pelajaran dapat membantu siswa belajar menggunakan konten pengetahuan lebih tepat dan fleksibel [11].

Materi Stoikiometri merupakan materi yang banyak memerlukan perhitungan dan penalaran untuk menyelesaikannya, sehingga siswa yang mempunyai kemampuan metakognisi tinggi dimungkinkan akan memiliki prestasi belajar yang lebih baik dari siswa dengan kemampuan metakognisi rendah. Metakognisi mempunyai peran penting dalam proses pembelajaran matematika khususnya pemecahan masalah [13].

Berdasarkan uraian tersebut, maka dilakukan penelitian terhadap komparasi model pembelajaran TAI berkombinasi Drill and Practice dan Problem Solving berbantuan Peer Tutoring ditinjau dari kemapuan metakognisi terhadap prestasi belajar siswa pada materi stoikiometri kelas X MIPA SMA N 1 Boyolali Tahun Ajaran 2016/2017.

\section{METODE PENELITIAN}

Penelitian ini dilaksanakan di SMA N 1 Boyolali pada kelas X MIPA Semester Genap Tahun Pelajaran 2016/2017. Metode penelitian yang digunakan adalah metode eksperimen dengan desain factorial $2 \times 2$. Adapun bagan desain penelitian disajikan pada Tabel 1 .

Tabel 1. Rancangan Penelitian Desain Faktorial $2 \times 2$

\begin{tabular}{cccc}
\hline \multirow{2}{*}{$\begin{array}{c}\text { Kelas } \\
\text { Eks }\end{array}$} & \multicolumn{1}{c}{$\begin{array}{c}\text { Model } \\
\text { Pembelajaran }\end{array}$} & \multicolumn{2}{c}{$\begin{array}{c}\text { Kemampuan } \\
\text { Metakognisi }\end{array}$} \\
\cline { 3 - 4 } & & $\begin{array}{c}\text { Tinggi } \\
\left(\mathrm{B}_{1}\right)\end{array}$ & $\begin{array}{c}\text { Rendah } \\
\left(\mathrm{B}_{2}\right)\end{array}$ \\
\hline $\mathrm{I}$ & $\begin{array}{l}\text { TAl-drill and } \\
\text { practice }\left(\mathrm{A}_{1}\right)\end{array}$ & $\mathrm{A}_{1} \mathrm{~B}_{1}$ & $\mathrm{~A}_{1} \mathrm{~B}_{2}$ \\
II & $\begin{array}{l}\text { Problem } \\
\text { solving-peer } \\
\text { tutoring }\left(\mathrm{A}_{2}\right)\end{array}$ & $\mathrm{A}_{2} \mathrm{~B}_{1}$ & $\mathrm{~A}_{2} \mathrm{~B}_{2}$ \\
\hline
\end{tabular}

Waktu penelitian dilaksanakan dari bulan Januari sampai September 2017 dengan subjek penelitian adalah 
siswa kelas $\mathrm{X}$ yang berjumlah 66 siswa yang terbagi menjadi 2 kelas, yaitu kelas $X$ MIPA 4 sebanyak 33 siswa dan $X$ MIPA 6 sebanyak 33 siswa dengan pertimbangan kedua kelas tersebut memiliki rata-rata kemampuan yang hampir sama. Kelas X MIPA 4 diberikan model TAI berkombinasi Drill and Practice dan kelas X MIPA 6 diberikan model Problem Solving berbantuan Peer Tutoring.

\section{HASIL DAN PEMBAHASAN}

Data yang diproleh pada penelitian ini adalah nilai kemampuan metakognisi dan prestasi belajar pada materi stoikiometri yaitu meliputi prestasi pengetahuan, sikap, dan keterampilan. Berikut ini disajikan data hasil penelitian dari masing-masing variabel.

\section{Data Prestasi Belajar Aspek Penge- tahuan}

Pada kelas eksperimen I, nilai tertinggi prestasi pengetahuan siswa adalah 4,00 , nilai terendahnya 1,40 , dan nilai rata-ratanya adalah 2,89. Pada kelas eksperimen II, nilai tertinggi prestasi pengetahuan siswa adalah 4,00 , nilai terendahnya 1,80 , dan nilai rata-ratanya adalah 2,74. Perbandingan distribusi frekuensi prestasi pengetahuan dapat dilihat pada Tabel 2 dan histogram perbandingan prestasi pengetahuan kedua kelas tersaji pada Gambar 1.

Tabel 2. Perbandingan Distribusi Frekuensi Prestasi Pengetahuan Siswa

\begin{tabular}{cccc}
\hline \multirow{2}{*}{ Interval } & \multirow{2}{*}{$\begin{array}{c}\text { Nilai } \\
\text { Tengah }\end{array}$} & \multicolumn{2}{c}{ Frekuensi } \\
\cline { 3 - 4 } & & $\begin{array}{c}\text { Kelas } \\
\text { Eks I }\end{array}$ & $\begin{array}{c}\text { Kelas } \\
\text { Eks II }\end{array}$ \\
\hline $1,40-1.83$ & 1,62 & 4 & 6 \\
$1,84-2,27$ & 2,06 & 6 & 6 \\
$2.28-2,71$ & 2,50 & 5 & 4 \\
$2,72-3,15$ & 2,94 & 5 & 4 \\
$3,16-3,59$ & 3,38 & 7 & 8 \\
$3,60-4,03$ & 3,82 & 6 & 5 \\
\hline \multicolumn{2}{c}{ Jumlah } & 33 & 33 \\
\hline
\end{tabular}

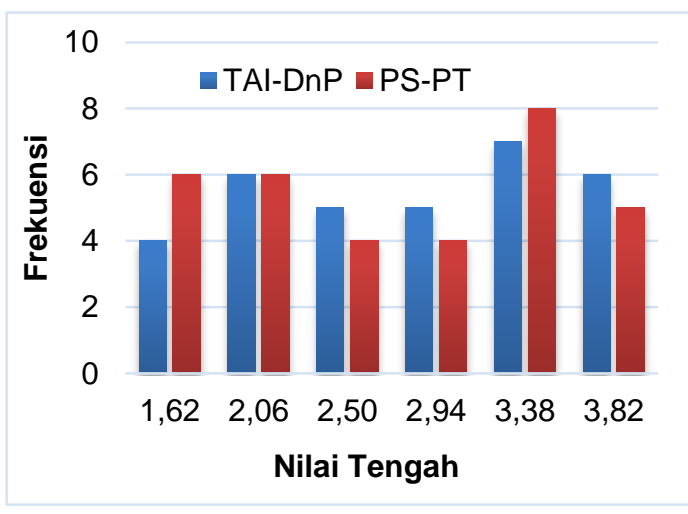

Gambar 1. Histogram Perbandingan Prestasi Pengetahuan Kelas Eksperimen I dan Eksperimen II

\section{Data Prestasi Belajar Aspek Sikap}

Pada kelas eksperimen I, nilai tertinggi prestasi sikap siswa adalah 4,00 , nilai terendah 2,00 , dan nilai rataratanya 3,06 . Untuk kelas eksperimen II nilai tertinggi prestasi sikap siswa adalah 4,00 , nilai terendah 2,00 , dan nilai rataratanya 2,91. Perbandingan distribusi frekuensi prestasi aspek sikap dapat dilihat pada Tabel 3 dan histogram perbandingan prestasi sikap kelas eksperimen disajikan pada Gambar 2.

Tabel 3. Perbandingan Distribusi Frekuensi Prestasi Sikap Siswa

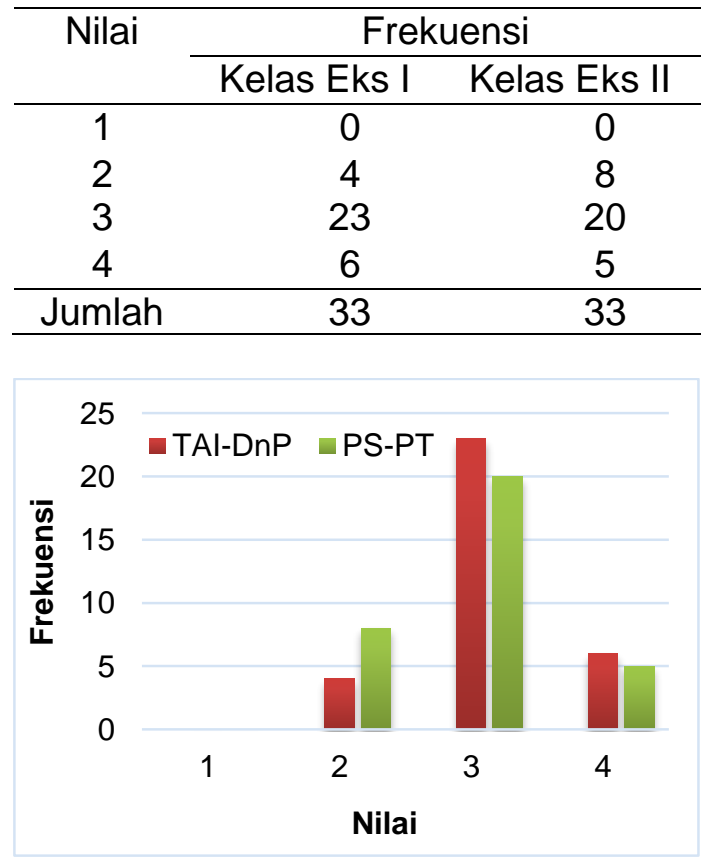

Gambar 2. Histogram Perbandingan Prestasi Sikap Kelas Eksperimen I dan Eksperimen II 


\section{Data Prestasi Belajar Aspek Keterampilan}

Pada kelas eksperimen I, nilai tertinggi prestasi keterampilan siswa adalah 3,70 , nilai terendah 3,00 , dan nilai rataratanya 3,20 . Untuk kelas eksperimen II nilai tertinggi prestasi sikap siswa adalah 3,70 , nilai terendah 2,80 , dan nilai rataratanya 3,40 . Perbandingan distribusi frekuensi prestasi aspek keterampilan dapat dilihat pada Tabel 4 dan histogram perbandingan prestasi sikap kelas eksperimen disajikan pada Gambar 3.

Tabel 2. Perbandingan Distribusi Frekuensi Prestasi Pengetahuan Siswa

\begin{tabular}{ccrr}
\hline \multirow{2}{*}{ Interval } & \multirow{2}{*}{$\begin{array}{c}\text { Nilai } \\
\text { Tengah }\end{array}$} & \multicolumn{2}{c}{ Frekuensi } \\
\cline { 3 - 4 } & & $\begin{array}{c}\text { Kelas } \\
\text { Eks I }\end{array}$ & $\begin{array}{c}\text { Kelas } \\
\text { Eks II }\end{array}$ \\
\hline $2,80-2,95$ & 2,88 & 0 & 2 \\
$2,96-3,11$ & 3,04 & 13 & 8 \\
$3,12-3,27$ & 3,20 & 6 & 1 \\
$3,28-3,43$ & 3,36 & 9 & 7 \\
$3,44-3,59$ & 3,52 & 3 & 11 \\
$3,60-3,75$ & 3,68 & 2 & 4 \\
\hline \multicolumn{2}{c}{ Jumlah } & 33 & 33 \\
\hline
\end{tabular}

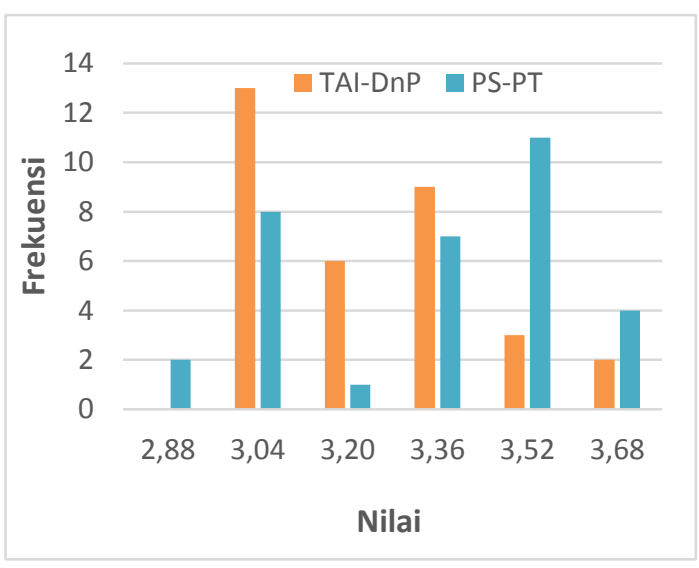

Gambar 3. Histogram Perbandingan Prestasi Keterampilan Kelas Eksperimen I dan Eksperimen II

\section{Pengujian Hipotesis}

Pengujian hipotesis dilakukan dengan analisis variansi (ANAVA) dua jalan dengan sel tak sama. Sebelum dilakukan uji ANAVA, data harus memenuhi uji prasyarat analisis yaitu uji normalitas dan uji homogenitas dengan bantuan software IBM SPSS v.21. Uji normalitas dilakukan untuk mengetahui apakah data penelitian berdistribusi normal, sedangkan uji homogenitas dilakukan untuk mengetahui kesamaan variansi data penelitian. Apabila data penelitian tidak memenuhi prasyarat tersebut, maka pengujian hipotesis dilakukan dengan uji statistik nonparametrik Kruskall Wallis $H$. hasil uji normalitas dan homogenitas data tersaji pada Tabel 5 dan Tabel 6.

Berdasarkan Tabel 5 dan Tabel 6, data penelitian yang memenuhi prasyarat analisis ANAVA adalah data prestasi pengetahuan, sedangkan data prestasi sikap dan keterampilan tidak memenuhi prasyarat analisis, sehingga pengujian hipotesis digunakan analisis non-parametrik Kruskall Wallis $H$.

\section{a. Hipotesis Pertama}

Hasil ANAVA dua jalan dengan sel tak sama untuk pengaruh model pembelajaran terhadap prestasi pengetahuan menunjukkan nilai Signifikansi (Sig.) $(0,015)<\alpha \quad(0,050)$ yang berarti $\mathrm{H}_{0 \mathrm{~A}}$ ditolak. Hal tersebut menunjukkan adanya pengaruh antara model TAI berkombinasi drill and practice dan model Problem Solving berbantuan Peer tutoring terhadap prestasi belajar siswa aspek pengetahuan pada materi stoikiometri. Besarnya rataan kelas Eksperimen I lebih besar $(2,89)$ dari kelas Eksperimen II (2,74), sehingga dapat diambil kesimpulan model pembelajaran TAI berkombinasi drill and practice dapat meningkatkan prestasi belajar aspek pengetahuan dengan lebih baik.

Sebagaiamana penelitian yang dilakukan oleh Sari [8] model pembelajaran TAI mampu meningkatkan prestasi belajar yang lebih baik. Model ini menggabungkan antara pembelajaran kooperatif dan pembelajaran individual. Sehingga, meskipun dalam perbandingan kedua model tersebut masingmasing memiliki seorang siswa yang berperan sebagai asissten atau tutor, dalam model TAl setiap siswa dalam kelompok tersebut tidak menggantungkan jawaban pada asisten. Terjadi proses tukar pikiran dan pendapat pada setiap anggota kelompok ketika diskusi berlangsung [7]. Latihan menggunakan 
drill and practice membantu setiap individu memiliki kesempatan lebih banyak untuk latihan soal. Dengan latihan berulangkali siswa akan lebih tangkas dan terlatih ketika mengerjakan soal-soal serupa [6].

Pada pelaksanaannya siswa yang diterapkan model pembelajaran TAI berkombinasi drill and practice pada materi stoikiometri akan lebih antusias belajar dibanding model pembelajaran Problem Solving berbantuan Peer tutoring. Hal tersebut dikarenakan pada akhir pembelajaran model TAI, bagi kelompok dengan skor terbaik akan diberikan reward. Lain halnya model pembelajaran Problem Solving, pada prosesnya siswa dalam kelompok dituntut dapat menyelesaikan persoalan dimulai dari mendefinisikan masalah hingga melakukan evaluasi. Walaupun dalam pelaksanaannya sudah dibantu adanya tutor, sebagian besar siswa masih merasa kesulitan dan pada akhirnya menggantungkan penyelesaian pada tutor. Hal inilah yang menyebabkan nilai prestasi aspek pengetahuan pada model pembelajaran TAI berkombinasi drill and practice lebih tinggi dibandingkan dengan model Problem Solving berbantuan peer tutoring.

Tabel 5. Hasil Uji Normalitas Prestasi Belajar Siswa Kelas Eksperimen I (TAI berkombinasi drill and practice) dan Eksperimen II (Problem Solving berbantuan peer tutoring)

\begin{tabular}{|c|c|c|c|c|c|c|c|}
\hline \multirow{2}{*}{$\begin{array}{c}\text { Kelompok } \\
\text { Siswa }\end{array}$} & \multirow{2}{*}{$\alpha$} & \multicolumn{2}{|c|}{ Pengetahuan } & \multicolumn{2}{|r|}{ Sikap } & \multicolumn{2}{|c|}{ Keterampilan } \\
\hline & & Sig. & Kesimpulan & Sig. & Kesimpulan & Sig. & Kesimpulan \\
\hline $\mathrm{A}_{1}$ & 0,050 & 0,465 & Normal & 0,000 & Tidak Normal & 0,018 & Tidak Normal \\
\hline $\mathrm{A}_{2}$ & 0,050 & 0,097 & Normal & 0,000 & Tidak Normal & 0,013 & Tidak Normal \\
\hline $\mathrm{B}_{1}$ & 0,050 & 0,051 & Normal & 0,000 & Tidak Normal & 0,002 & Tidak Normal \\
\hline $\mathrm{B}_{2}$ & 0,050 & 0,166 & Normal & 0,000 & Tidak Normal & 0,013 & Tidak Normal \\
\hline$A_{1} B_{1}$ & 0,050 & 0,350 & Normal & 0,000 & Tidak Normal & 0,002 & Tidak Normal \\
\hline$A_{1} B_{2}$ & 0,050 & 0,911 & Normal & 0,000 & Tidak Normal & 0,038 & Tidak Normal \\
\hline $\mathrm{A}_{2} \mathrm{~B}_{1}$ & 0,050 & 0,144 & Normal & 0,000 & Tidak Normal & 0,029 & Tidak Normal \\
\hline $\mathrm{A}_{2} \mathrm{~B}_{2}$ & 0,050 & 0,057 & Normal & 0,000 & Tidak Normal & 0,005 & Tidak Normal \\
\hline
\end{tabular}

Tabel 6. Hasil Uji Homogenitas Prestasi Belajar Siswa Kelas Eksperimen I (TAI berkombinasi drill and practice) dan Eksperimen II (Problem Solving berbantuan peer tutoring)

\begin{tabular}{lccccccc}
\hline \multirow{1}{c}{ Uji } & \multirow{2}{*}{$\alpha$} & \multicolumn{2}{c}{ Pengetahuan } & \multicolumn{2}{c}{ Sikap } & \multicolumn{2}{c}{ Keterampilan } \\
\cline { 3 - 7 } Homogenitas & & Sig. & Kesimpulan & Sig. & Kesimpulan & Sig. & Kesimpulan \\
\hline $\begin{array}{l}\text { Ditinjau dari } \\
\text { Model }\end{array}$ & 0,050 & 0,553 & Homogen & 0,188 & Homogen & 0,056 & Homogen \\
$\begin{array}{l}\text { Pembelajaran } \\
\begin{array}{l}\text { Ditinjau dari } \\
\text { Kemampuan }\end{array}\end{array}$ & 0,050 & 0,925 & Homogen & 0,507 & Homogen & 0,694 & Homogen \\
$\begin{array}{l}\text { Metakognisi } \\
\text { Antar Sel }\end{array}$ & 0,050 & 0,673 & Homogen & 0,643 & Homogen & 0,051 & Homogen \\
\hline
\end{tabular}

Hasil uji statistik non-parametrik Kruskal Wallis $H$ pada pengaruh model pembelajaran terhadap prestasi belajar aspek sikap menunjukkan nilai signifikansi (Sig.) $(0,056)>a(0,050)$ dan pada prestasi belajar aspek keterampilan (Sig.) $(0,132)>\alpha(0,050)$ yang artinya $\mathrm{H}_{0 \mathrm{~A}}$ diterima.
Hasil ini berarti bahwa penerapan model TAI berkombinasi drill and practice dan problem solving berbantuan peer tutoring tidak memberikan pengaruh yang signifikan terhadap prestasi sikap dan keterampilan siswa pada materi stoikiometri. Besarnya rataan prestasi sikap model TAI berkombinasi drill and practice adalah 3,06 sedang- 
kan model problem solving berbantuan peer tutoring adalah 2,91. Pada prestasi belajar aspek keterampilan model TAI berkombinasi drill and practice memberikan rataan sebesar 3,20 sedangkan model problem solving berbantuan peer tutoring sebesar 3,40 . Sehingga dapat diambil kesimpulan penerapan model TAl berkombinasi drill and practice memberikan hasil prestasi belajar aspek sikap dan keterampilan yang sama baiknya dengan model problem solving berbantuan peer tutoring.

Hal ini karena sikap seorang siswa lebih dipengaruhi oleh faktor internal dari dalam diri siswa, seperti pengalaman individu, kebudayaan, institusi atau lembaga pendidikan agama, media massa atau teknologi, dan faktor emosional. Sedangkan model pembelajaran merupakan faktor eksternal, sehingga tidak akan berpengaruh pada prestasi sikap siswa. Prestasi belajar aspek sikap tidak dapat dilihat dari satu atau dua pertemuan saja, karena sikap merupakan suatu hasil proses penenrapan nilai yang harus dilakukan secara bertahap. Hasil ini didukung oleh penelitian Sari [8] yang menunjukkan tidak adanya pengaruh metode TAI dan CPS terhadap prestasi belajar afektif pada materi kelarutan dan hasil kali kelarutan.

Aspek keterampilan siswa yang diajar model TAI berkombinasi drill and practice maupun model problem solving berbantuan peer tutoring sama-sama melibatkan siswa untuk aktif pada kegiatan diskusi kelompok dan presentasi. Kegiatan ini sudah terbiasa dilakukan siswa dalam keseharian kegiatan pembelajaran kimia disekolah. Hal ini dapat membentuk siswa memiliki keterampilan dalam berdiskusi dan presentasi. Penilaian aspek keterampilan dilakukan pada saat kegiatan pembelajaran berlangsung melalui observasi. Dari hasil tersebut, siswa-siswa dari kedua kelas eksperimen mampu mencapai nilai keterampilan yang baik.

\section{b. Hipotesis Kedua}

Hasil uji ANAVA dua jalan dengan sel tak sama untuk pengaruh kemampuan metakognisi terhadap prestasi belajar aspek pengetahuan menunjukkan nilai signfikansi (Sig.) $(0,066)>a$
$(0,050)$ yang berarti $\mathrm{H}_{0 \mathrm{~B}}$ diterima. Hal ini menunjukkan tidak adanya pengaruh perbedaan yang signifikan antara siswa yang memiliki tingkat kemampuan metakognisi tinggi dan rendah terhadap prestasi belajar siswa aspek pengetahuan siswa pada materi stoikiometri.

Tidak adanya perbedaan kemampuan metakognisi terhadap prestasi belajar aspek pengetahuan dimungkinkan akibat proses pembelajaran menggunakan kedua model pembelajaran siswa dikelompokkan secara heterogen, sehingga siswa dapat berbagi pengetahuan satu sama lain (siswa dengan kemampuan metakognisi tinggi dapat membantu siswa dengan metakognisi rendah). Namun demikian, menurut Doyle [14] untuk dapat berfungsi dengan baik siswa dengan kemampuan metakognisi tinggi harus memiliki pemikiran yang tajam, belajar bagaimana belajar yang baik, dan tahu bagaimana mengapliksikan pengetahuannya. Peran guru sangat diperlukan untuk memanfaatkan kemampuan metakognisi dalam mengembangkan pengetahuan, meningkatkan berfikir kritis, dan membantu dalam mengambil keputusan yang bijak [15]. Dengan demikian, kemampuan metakognisi tidak hanya mensyaratkan kemampuan kognisi yang tinggi, tetapi juga siswa harus tahu kapan dan bagaimana menggunakan strategi dalam menyelesaikan persoalan. Dalam pelaksanaannya, beberapa siswa dengan kemampuan metakognisi tinggi mudah menyerah ketika dihadapkan pada persoalan yangbelum pernah diselesaikan atau mereka tidak tahu bagaimana memulai menyelesaikan soal tersebut.

Kemampuan metakognitif dapat berkembang jika dilatih dan dikembangkan. Berdasarkan penenlitian yang dilakukan Danial [16] terkait kemampuan metakognisi dalam pemebelajaran kimia dasar, sebagian besar mahasiswa memiliki kemampuan metakognisi tinggi namun belum terlatih dan terorganisasi serta terencana. Dengan tidak terencananya metakognisi yang dimiliki dapat memberikan dampak lemah terhadap hasil belajar kognitis itu sendiri.

Hasil uji statistik non-parametrik Kruskal Wallis H pada pengaruh kemam- 
puan metakognisi terhadap prestasi belajar aspek sikap menunjukkan nilai signifikansi (Sig.) $(0,061)>\alpha(0,050)$ dan pada prestasi belajar aspek keterampilan (Sig.) $(0,062)>\alpha(0,050)$ yang artinya $\mathrm{H}_{O B}$ diterima. Hal ini menunjukkan bahwa tidak ada pengaruh kemampuan metakognisi tinggi dan rendah terhadap prestasi sikap dan keterampilan siswa pada materi stoikiometri.

Tidak adanya perbedaan antara kemampuan metakognisi tinggi dan rendah dalam prestasi belajar aspek sikap dapat disebabkan karena metakognisi mencakup pengetahuan tentang proses berifkir kita sendiri, regulasi diri, memantau apa yang sedang kita kerjakan dapat membantu (atau tidak dapat membantu) mengatasi masalah [17]. Sedangkan sikap bermula dari perasaan (suka atau tidak suka) yang terkait dengan kecenderungan seseorang dalam merespon suatu objek [18]. Dari kedua definisi tersebut, tampak bahwa kemampuan metakognisi tidak berhubungan langsung dengan prestasi aspek sikap. Hasil ini didukung dengan penelitian sebelumnya oleh Nadi [19] yang menyatakan bahwa tidak terdapat pengaruh secara signifikan antara kemampuan metakognisi terhadap prestasi belajar sikap pada materi Ksp.

Tidak adanya perbedaan kemampuan metakogisi terhadap prestasi belajar aspek keterampilan kemungkinan disebabkan karena siswa yang memiliki kemampuan metakognsisi tinggi ataupun rendah sama-sama terlibat aktif dalam kegiatan kelompok seperti diskusi, pemecahan masalah, dan presentasi sehingga berpengaruh pada penialain keterampilan dengan observassi. Menurut Desmita [20], kemampuan meta-kognisi lebih cenderung dalam ranah kog-nitif, karena aspek keterampilan berkaitan dengan keterampilan (skill) atau kemampuan bertindak siswa dalam kegiatan kelompok.

\section{c. Hipotesis Ketiga}

Hasil uji ANAVA dua jalan dengan sel tak sama untuk pengaruh efek interaksi terhadap prestasi pengetahuan menunjukkan nilai signifikansi (Sig.) $(0,317)>\alpha(0,050)$ yang berarti $\mathrm{H}_{O A B}$ diterima. Hasil uji statistik non parametrik Kruskal Wallis untuk pengaruh efek interaksi terhadap prestasi sikap menunjukkan nilai signifikansi $(0,328)>\alpha$ taraf signifikansi $(0,05)$ dan pada prestasi belajar aspek keterampilan (Sig.) $(0,804)>a(0,050)$ yang berarti $\mathrm{H}_{O A B}$ diterima. Hal ini menunjukkan bahwa tidak ada interaksi antara model TAI berkombinasi drill and practice dan model Problem Solving berbantuan peer tutoring dengan kemampuan metakognisi terhadap prestasi pengetahuan, sikap, dan keterampilan siswa pada materi stoikiometri. Tidak adanya interaksi tersebut menunjukkan bahwa siswa dengan kemampuan metakognisi tinggi dan rendah mempunyai efek yang sama terhadap prestasi pengetahuan, sikap, dan keterampilan pada kelas yang dikenai model TAl berkombinasi drill and practice maupun model Problem Solving berbantuan peer tutoring.

\section{KESIMPULAN}

Berdasarkan hasil penelitian dapat disimpulkan bahwa: (1) terdapat pengaruh model pembelajaran TAI berkombinasi drill and practice dan model Problem Solving berbantuan peer tutoring pada prestasi belajar aspek pengetahuan, tetapi tidak berpengaruh pada aspek sikap dan keterampilan siswa pada materi stoikiometri. (2) Tidak ada pengaruh kemampuan metakognisi tinggi dan rendah terhadap prestasi pengetahuan, sikap, dan keterampilan siswa pada materi stoikiometri. (3) Tidak ada interaksi antara model TAI berkombinasi drill and practice dan model Problem Solving berbantuan peer tutoring dengan kemampuan metakognisi terhadap prestasi belajar aspek pengetahuan, sikap, dan keterampilan siswa pada materi stoikiometri.

\section{UCAPAN TERIMA KASIH}

Bapak Drs. Agung Wardoyo selaku Kepala SMA N 1 Boyolali yang telah memberikan ijin penelitian serta Ibu Dwi Yuliasih, M.Pd. selaku guru mata pelajaran kimia Kelas X SMA N 1 Boyolali yang telah memberikan bimbingan dan bantuan selama melaksanakan penelitian. 


\section{DAFTAR RUJUKAN}

[1] Kementrian Pendidikan dan Kebudayaan. (2012). Konsep dan Implementasi Kurikulum 2013, Jakarta: Sekretarian Jendral.

[2] Setiadi, Hari., dkk. (2011). Profil Kemampuan IPA Peserta Didik Indonesia berdasarkan Benchmark Internasional TIMSS 2011. Jakarta: Pusat Penilaian Pendidikan Badan Penilaian dan Pengembangan Kementerian Pendidikan dan Kebudayaan.

[3] Latisma, D. (2015). Proceeding The International Conference on Education, Mathematic, Science and Technology for Human \& Natural Resource, 250-255.

[4] Hanson, Ruby. (2016). Journal of Education and e-Learning Research, 3(1).

[5] Tilaar, A.L.F. (2014). International Journal of Science and Engineering Investigations, 3(24), 25-29.

[6] Fitriana, D., Ashadi., \& Saputro, A.N.C. (2016). Jurnal Pendidikan Kimia (JPK), 5(3), 27-35.

[7] Awofala, A.O.A., Arigbabu, A.A., \& Awofala, A.A. (2013). Acta Didactica Napocensia, 6(1), 1-22.

[8] Sari, D.K., Mulyani, B., \& Mulyani, S. (2014). Jurnal Pendidikan Kimia (JPK), 3(1), 51-57.

[9] Kim, M.C. \& Hannafin, M.J. (2011). Elsevier: Journal Computers \& Education, 56(1), 403-417.

[10] Ishartono, B., Ashadi, Susilowati, E. (2015). Jurnal Pendidikan Kimia, 1(4). 10-11, 10-19.
[11] Rickey, Dawn. \& Stacy, A.M. (2000). Journal of Chemical Education, (77)7, 915-920.

[12] Schunk, D. H. (2012). Teori Pembelajaran Perspektif Pendidikan. Ter. Eva H \& Rahmat $\mathrm{F}$. Yogyakarta: Pustaka Pelajar.

[13] Mahromah, L.A., \& Manoy, J.T. (2013). Jurnal IImiah Pendidikan Matematika, 2(1).

[14] Doyle, B.P. (2013). Metacognitive Awareness: Impact of a Metacognitive Intervention in a Prenursing Course. Disertasi, Louisiana State University.

[15] Java, L.A. (2014). Problem Solving Strategies and MetacognitiveSkills For Gifted Students In Middle School. Tesis, Louisiana State University.

[16] Danial, Muhammad. (2010). Jurnal Chemica, 11(2), 1-10.

[17] Greadler, C.J. (2011). Learning and Instruction: Teori dan Aplikasi. Terj. Tri Wibowo B.S. Jakarta: Kencana.

[18] Peraturan Menteri Pendidikan dan Kebudayaan Nomor 104. (2014). Penilaian Hasil Belajar Oleh Pendidik Pada Pendidikan Dasar dan Pendidikan Menengah. Jakarta Kemendikbud.

[19] Nadi, C.Y., ES. Agustina, W., \& Saputro, S. (2016). Jurnal Pendidikan Kimia (JPK), 5(1), 125133.

[20] Desmita. (2011). Psikologi Perkembangan Peserta Didik. Bandung: Rosdakarya 